Communication

\title{
Enhanced Performance of Immobilized Xylanase/Filter Paper-ase on a Magnetic Chitosan Support
}

\author{
Aldo Amaro-Reyes ${ }^{1, * \mathbb{D}}$, Azariel Díaz-Hernández ${ }^{1}$, Jorge Gracida ${ }^{2}$, \\ Blanca E. García-Almendárez ${ }^{1}$, Monserrat Escamilla-García ${ }^{2}$, Teresita Arredondo-Ochoa ${ }^{1}$ and \\ Carlos Regalado ${ }^{1}$ (D) \\ 1 DIPA, PROPAC, Facultad de Química, Universidad Autónoma de Querétaro, Centro Universitario, Cerro de \\ las Campanas s/n Col. Las Campanas, Querétaro 76010, Mexico; azarieldh07@gmail.com (A.D.-H.); \\ blancag31@gmail.com (B.E.G.-A.); arredondo.tere@yahoo.com (T.A.-O.); regcarlos@gmail.com (C.R.) \\ 2 Facultad de Química, Universidad Autónoma de Querétaro, Centro Universitario, Cerro de las Campanas s/n \\ Col. Las Campanas, Querétaro 76010, Mexico; jgracida@gmail.com (J.G.); monse41214@gmail.com (M.E.-G.) \\ * Correspondence: aldo.amaro@uaq.edu.mx; Tel.: +52-442-192-1267; Fax: +52-442-192-1302
}

Received: 16 August 2019; Accepted: 13 November 2019; Published: 16 November 2019

check for updates

\begin{abstract}
Enzyme immobilization on different supports has emerged as an efficient and cost-effective tool to improve their stability and reuse capacity. This work aimed to produce a stable immobilized multienzymatic system of xylanase and filter paper-ase (FPase) onto magnetic chitosan using genipin as a cross-linking agent and to evaluate its biochemical properties and reuse capacity. A mixture of chitosan magnetic nanoparticles, xylanase, and FPase was covalently bonded using genipin. Immobilization yield and efficiency were quantified. The activity of free and immobilized enzymes was quantified at different values of $\mathrm{pH}$, temperature, substrate concentration ( $\mathrm{Km}$ and Vmax), and reuse cycles. The immobilization yield, immobilization efficiency, and activity recovery were $145.3 \% \pm 3.06 \%, 14.8 \% \pm 0.81 \%$, and $21.5 \% \pm 0.72 \%$, respectively, measured as the total hydrolytic activity. Immobilization confers resistance to acidic/basic conditions and thermal stability compared to the free form. Immobilization improved 3.5-fold and 78-fold the catalytic efficiency (Kcat/Km) of the xylanase and filter paper-ase activities, while immobilized xylanase and FPase could be reused for $34 \mathrm{~min}$ and $43 \mathrm{~min}$, respectively. Cross-linking significantly improved the biochemical properties of immobilized enzymes, combined with their simplicity of reuse due to the paramagnetic property of the support. Multienzyme immobilization technology is an important issue for industrial applications.
\end{abstract}

Keywords: hydrolytic enzymes; nanobiocatalyst; nanoparticles; catalytic efficiency

\section{Introduction}

Among the numerous compounds employed to formulate polymeric nanoparticles, chitosan has been used due to its biodegradability, biocompatibility, and non-toxicity [1]. Genipin is commonly used in pharmaceutical, food, and health industries due to its unique biocompatibility and low cytotoxicity relative to conventional cross-linkers such as glutaraldehyde and epoxy compounds (5000-10,000 fold) [2,3]. Since genipin can cross-link amino-group-containing molecules, it has been used as a support activator for enzyme immobilization [4,5]. Enzymes show great potential for scientific and industrial processes because of their highly efficient catalytic mechanisms and substrate selectivity [6]. However, free enzymes are generally unstable, practically non-reusable and many are denatured at relatively low temperatures. Enzyme immobilization on different supports has emerged as an efficient and cost-effective tool to improve their stability and reuse capacity [7]. Additionally, enzyme immobilization may alter their activity, specificity, or selectivity, which could be a tool to improve 
enzyme properties (although an opposite effect is observed in many cases) [8,9]. Moreover, in recent years, the development of immobilized multienzymatic systems is increasingly guided by economic and environmental drawbacks, leading to the development of new multistep synthetic methods [10]. Further, it has been reported that multienzyme immobilization could confer superior activity, stability, and performance compared to individual immobilized enzymes, especially when using complex substrates [11-13]. However, among the disadvantages of multienzyme immobilization are the different stabilities of each biocatalyst involved, protocol design, or the occurrence of undesired interactions [14]. Other shortcomings to consider are that when the least-stable enzyme is inactivated, both enzymes need to be discarded, and usually immobilization protocols on the same support may not be optimal for all enzymes $[9,15]$. Thus, efforts have been made to assess the impact of the immobilization procedure on operational stability, productivity, efficiency, and mass transfer within multienzymatic systems [16-18]. On the other hand, enzyme immobilization on a nano-polymeric matrix can improve enzyme stability as well as reuse capacity, but some drawbacks should be avoided, such as the cost of the fabrication process, large-scale application, and separation of the reaction medium [8]. Additionally, magnetic nanoparticles have attracted special attention as functional carriers and supporting matrices for immobilization applications due to their large surface area and surface-to-volume ratio, mobility, high mass transfer, and ease of separation and recovery by using an external magnetic field $[19,20]$.

In this context, a combination of hemicellulolytic enzymes such as FPase and xylanase has been applied in biorefineries to break down the complex plant cell wall, releasing fermentable sugars that can be used for the manufacture of high-value materials [18,21]. This goal may be achieved by designing and characterizing an efficient multi-enzyme system to take advantage of the full potential of the biorefinery concept. This work aimed to produce a stable immobilized multienzymatic system of xylanase and FPase onto magnetic chitosan using genipin as a cross-linking agent and to evaluate the biochemical properties and reuse capacity of this enzymatic system.

\section{Results and Discussion}

\subsection{Immobilization Yield and Efficiency}

The magnetic chitosan composite was synthesized in a single step, and was covalently bonded to two enzymes using a natural and low-toxicity cross-linking agent. The structural characterization of magnetic nanoparticles cross-linked to two hydrolytic enzymes has been previously described [22]. The immobilization yield, efficiency, and activity recovery were $145.3 \% \pm 3.06 \%, 14.8 \% \pm 0.81 \%$, and $21.5 \% \pm 0.72 \%$, respectively, measured as the total hydrolytic activity. In this work, a synthetic complex substrate was used to quantify the total hydrolytic activity. According to [23], three parameters determine the success of enzyme immobilization. One is the immobilization yield, which describes the percentage of free total hydrolytic activity (both xylanase and filter paper-ase (FPase)) that is immobilized. The immobilization efficiency is another critical parameter, and describes the percentage of total hydrolytic activity observed in the immobilizate. The last parameter is activity recovery, where the total hydrolytic activity of the immobilizate is compared to the total starting activity of the free enzymes. Many reports have shown a wide variety of results for immobilization yield and efficiency that are attributed to the nature of the immobilization protocol, supporting material, cross-linker agent, and the particular sizes of enzymes and their substrates $[6,7,10,19]$. A synergistic effect was demonstrated when using immobilized enzymes degrading complex substrates rather than using a mixture of individual immobilized enzymes, which was attributed to the reduction of product inhibition, a limit to the accumulation of intermediates, and more bound enzymes able to attack large substrates, minimizing steric hindrance $[11,13,17]$. Cross-linking alters the microstructure of chitosan by the formation of covalent bonds between enzymes and $\mathrm{Fe}_{3} \mathrm{O}_{4} @$ chitosan, as was previously discussed [22], thus impacting in biochemical behavior of the biocatalyst. While the effect on the enzyme is variable, affecting its activity, stability, selectivity, specificity, inhibition, resistance to chemicals, recovery, and reuse capacity, changes in mechanical strength and stability were also reviewed $[10,24]$. Among usual cross-linkers 
such as glutaraldehyde, carbodiimide/N-hydroxysuccinimide, and epoxy-based materials, genipin is commonly used because it is a natural product extracted from the herb Gardenia jasminoides Ellis showing highly reduced cytotoxicity, cross-linking chitosan using the amino groups [25].

\subsection{Effect of $\mathrm{pH}$ and Temperature on Xylanase and Filter paper-ase Activity}

Figure 1 shows the effect of $\mathrm{pH}$ on the specific activity of free and immobilized xylanase and FPase enzymes. As shown in Figure 1a, the maximum activity of free and immobilized xylanase was observed at $\mathrm{pH} 6$ and $\mathrm{pH} 4$, with values of 1.97 and $3.57 \mathrm{U} / \mathrm{mg}$ protein, respectively, indicating that the activity was higher under drastic $\mathrm{pH}$ values. This finding suggests that the support provided stability to immobilized xylanase at acidic $\mathrm{pH}$ values when compared to the free enzyme. Figure $1 \mathrm{~b}$ shows that the optimal FPase activity was kept at $\mathrm{pH} 4$, with values of 0.05 and $0.13 \mathrm{U} / \mathrm{mg}$ protein, both for the free and immobilized enzyme. However, immobilized FPase showed a 2.6-fold enhancement in catalytic activity.

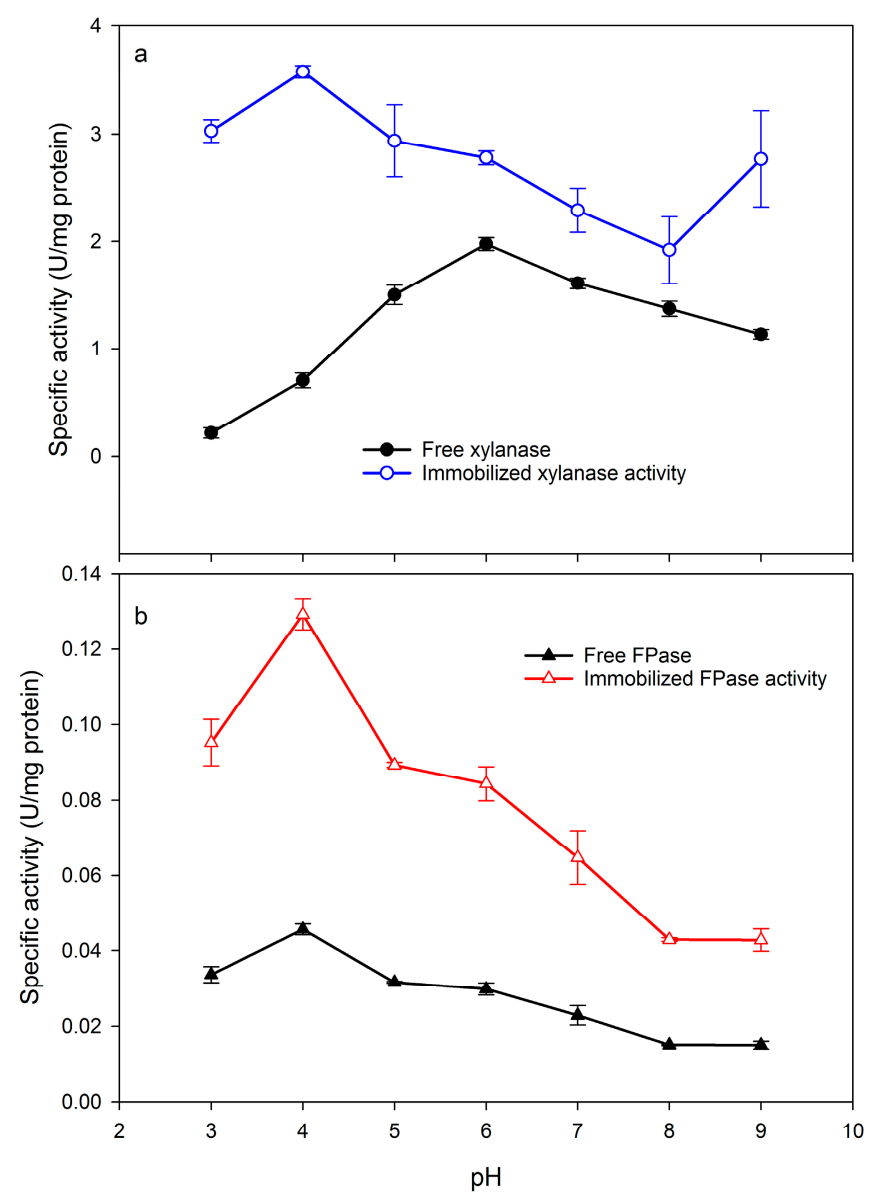

Figure 1. Effect of $\mathrm{pH}$ on the relative activity of (a) free (black full circle) and immobilized (blue open circle) xylanase and (b) free (black full triangle) and immobilized (red open triangle) filter paper-ase (FPase). One unit (U) of xylanase and FPase activity is defined as the amount of enzyme catalyzing the release of $1 \mu \mathrm{mol}$ of reducing sugar as xylose or glucose equivalent per minute under the specified assay conditions.

The immobilized enzymes showed improved temperature stability compared to the free enzymes in the range 30 to $90^{\circ} \mathrm{C}$, as shown in Figure 2a,b. The temperature showing the maximum activity of the free and immobilized xylanase was $70^{\circ} \mathrm{C}$, while for the free and immobilized FPase it was $60^{\circ} \mathrm{C}$. The values of activation energy (Ea) estimated from the Arrhenius plots were $45.9 \mathrm{~kJ} / \mathrm{mol}\left(R^{2}=0.92\right)$ for free xylanase and $13.9 \mathrm{~kJ} / \mathrm{mol}\left(R^{2}=0.88\right)$ for immobilized xylanase; $39.7 \mathrm{~kJ} / \mathrm{mol}\left(R^{2}=0.94\right)$ for free 
FPase and $21.3 \mathrm{~kJ} / \mathrm{mol}\left(R^{2}=0.88\right)$ for immobilized FPase. These values represent a 3.3-fold decrease in Ea for immobilized xylanase and a 1.9-fold decrease for immobilized FPase relative to the free enzymes.

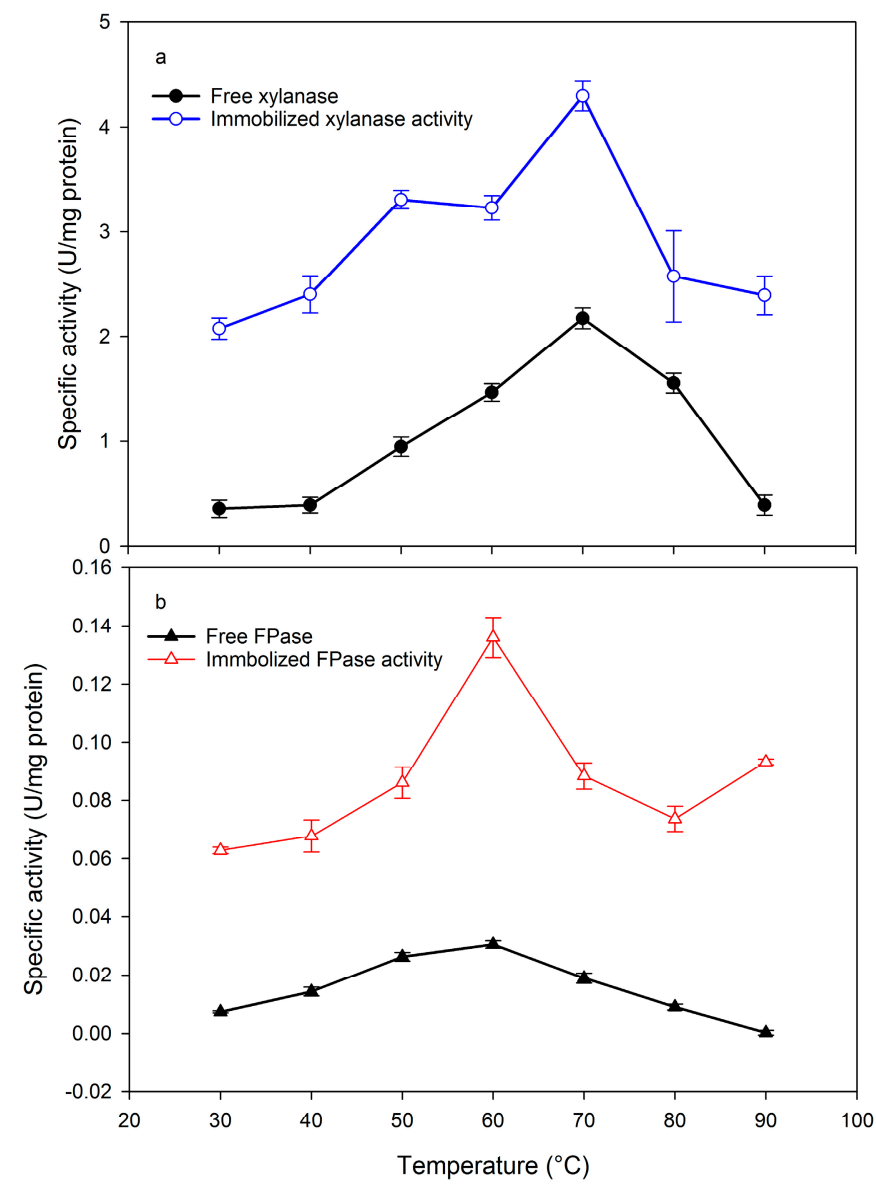

Figure 2. Effect of temperature on the relative activity of (a) free (black full circle) and immobilized (blue open circle) xylanase and (b) free (black full triangle) and immobilized (red open triangle) FPase. One unit (U) of xylanase and FPase activity is defined as the amount of enzyme catalyzing the release of $1 \mu \mathrm{mol}$ of reducing sugar as xylose or glucose equivalent per minute under the specified assay conditions.

The changes observed at acidic $\mathrm{pH}$ values (Figure 1) may be explained by the ionic interactions between the enzyme and the support's surface [26]. In addition, internal $\mathrm{pH}$ gradients may be formed in enzymes immobilized on porous supports due to diffusion limitations of both substrate and product, resulting in $\mathrm{pH}$ changes away from the optimal found in the bulk [9]. Above the optimum temperature of activity, we observed a gradual decline in free and $\mathrm{Fe}_{3} \mathrm{O}_{4} @$ chitosan@enzymes activities (Figure 2), probably due to the disruption of ionic interactions and partial weakening of covalent bonds, which distort structural conformation of enzymes as described by [27].

Better thermal stability was observed for both enzymes (Figure 2) associated with the newly formed covalent bonds between enzymes and magnetic nanoparticles $[5,28]$. The temperature dependence of the catalytic reaction rate observed through the Arrhenius equation evidences the improvement that immobilization can produce in enzymes' conformational changes as reported by $[12,27,28]$, thus, the immobilized enzymes were able to catalyze the hydrolysis of substrates with a lower Ea when compared to free enzymes. 


\subsection{Kinetic Parameters of Xylanase and FPase}

The Michaelis-Menten kinetic parameters of free and immobilized xylanase and FPase were calculated using the Lineweaver-Burk linearization, and are shown in Table 1. After xylanase immobilization on the magnetic composite, it showed increased kinetic parameters compared to the free enzyme: 1.7-fold in $\mathrm{Km}$, 1.8-fold in Vmax, 2.9-fold in Kcat, and 1.8-fold in the catalytic efficiency (Kcat $/ \mathrm{Km}$ ). In contrast, immobilized FPase compared to the free enzyme showed a 9.4-fold decrease in $\mathrm{Km}$, a 1.4-fold increase in Vmax, a 3.8-fold increase in Kcat, and 33-fold increase in catalytic efficiency. It must be pointed out that Kcat values were calculated assuming equal amounts of both enzymes were attached to the support.

Table 1. Michaelis-Menten kinetic parameters of free and immobilized xylanase and FPase.

\begin{tabular}{cccccc}
\hline Enzyme & Form & $\begin{array}{c}\mathbf{K m} \\
\mathbf{( m g / m L )}\end{array}$ & $\begin{array}{c}\text { Vmax } \\
\mathbf{( U / m L )}\end{array}$ & Kcat (1/s) & $\begin{array}{c}\text { Kcat/Km } \\
\mathbf{( m L / m g ~ s ) ~}\end{array}$ \\
\hline \multirow{2}{*}{ Xylanase } & $\begin{array}{c}\text { Free } \\
\text { Immobilized }\end{array}$ & $1.89 \pm 0.46$ & $6.31 \pm 0.63$ & $7.01 \pm 0.70$ & $3.71 \pm 0.57$ \\
& $3.15 \pm 0.16$ & $11.6 \pm 0.26$ & $20.4 \pm 0.90$ & $6.50 \pm 0.04$ \\
\hline \multirow{2}{*}{ FPase } & Free & $157 \pm 87$ & $2.06 \pm 0.88$ & $1.04 \pm 0.44$ & $0.007 \pm 0.00$ \\
& Immobilized & $16.7 \pm 1.6$ & $2.82 \pm 0.07$ & $3.92 \pm 0.19$ & $0.235 \pm 0.01$ \\
\hline
\end{tabular}

All values represent the mean of experiments in triplicate $(n=3) \pm$ standard deviation. One unit $(\mathrm{U})$ of xylanase and FPase activity is defined as the amount of enzyme catalyzing the release of $1 \mu \mathrm{mol}$ of reducing sugar as xylose or glucose equivalent per minute $\left(\mathrm{pH} 6,70{ }^{\circ} \mathrm{C}\right.$ for free xylanase; $\mathrm{pH} 4,70{ }^{\circ} \mathrm{C}$ for immobilized xylanase; and $\mathrm{pH} 4$, $60{ }^{\circ} \mathrm{C}$ for free and immobilized FPase).

High $\mathrm{Km}$ values are related to a low affinity of enzymes for their substrate, and thus lower $\mathrm{Km}$ values are related to a higher affinity (Table 1). An increase in Vmax indicates a faster rate of product formation in the catalytic reaction (Table 1). When the turnover number (Kcat) is large, product formation in catalysis is more favorable. Additionally, higher catalytic efficiency (Kcat/Km) reflects a better ability of the enzyme to interact with the substrate and convert it into products (Table 1).

The apparent improvement in enzyme performance after cross-linking (Table 1) could be related to a high surface-area-to-volume ratio and increased the diffusion of substrates within immobilized magnetic nanoparticles $[17,27]$. It is hypothesized that a higher concentration of substrate in the limited space of the enzyme complex led to an increased frequency of interactions between immobilized enzymes and their respective substrate [12]. Furthermore, variations in the affinity of immobilized enzymes with their substrates could be explained by the formation of new bonds in the cross-linking reaction, which limited (xylanase) or favored (FPase) flexibility of the enzymes and thus the accessibility of macromolecular substrates [29]. Further comparison between individually immobilized enzymes and the immobilized multi-enzyme system should be done to assess a possible synergistic effect.

\subsection{Reuse Capacity of $\mathrm{Fe}_{3} \mathrm{O}_{4} @$ Chitosan@Enzymes}

Figure 3 shows the reuse capacity of the immobilized enzymes under optimal conditions of activity for $10 \mathrm{~min}$ in discontinuous mode. After each cycle, the multienzymatic nanobiocatalyst was magnetically separated, rinsed, and added to a fresh substrate. The catalytic activity of xylanase decreased to $49 \%$ of its initial value after the fourth reaction cycle, while FPase activity decreased to $52 \%$ in the fifth cycle. By the sixth cycle, the xylanase activity dropped to $22 \%$ and the FPase residual activity was $23 \%$ until the eighth cycle. The time required for the activity to decrease to half its original activity $\left(\mathrm{t}_{1 / 2}\right)$ for xylanase was $34 \min \left(R^{2}=0.91\right)$ and for FPase it was $43 \min \left(R^{2}=95\right)$.

Separation and recovery of the immobilized enzymes by an external magnetic field makes this process highly convenient, where the reuse for multiple cycles is easily achieved, reducing the total processing costs [30]. Slightly better stability was observed on the residual activity of FPase compared to the xylanase, where the bonding force to the magnetic composite of the latter could be lower, or else interference between the two macromolecular substrates could be affecting interactions with the active site of xylanase. A novel strategy to overcome the problem of low stability could be to immobilize the 
labile and hard-to-stabilize enzyme by ion exchange on the already-immobilized resistant enzyme to desorb the least-stable enzyme when its activity decreases.

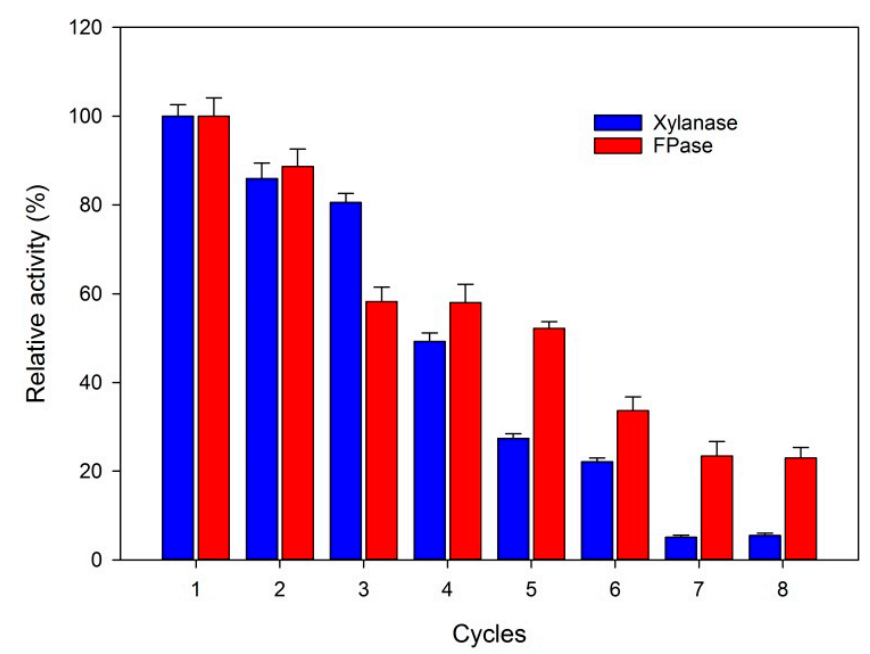

Figure 3. Reuse capacity of $\mathrm{Fe}_{3} \mathrm{O}_{4} @$ Chitosan@Enzymes over eight consecutive cycles incubated at optimal $\mathrm{pH}$ and temperature for $10 \mathrm{~min}$. The co-immobilized enzymes were incubated with a new reaction medium to start a new hydrolysis cycle. The data points represent the mean values of three replicates \pm standard deviation.

Other authors have reported outstanding reusability when using immobilized hydrolase systems, attributed to high retention of biocatalysts in the nanoparticles [11,17]. However, previous studies using a complex of hydrolytic enzymes immobilized on magnetic particles have reported activity drops to $20 \%$ after the second reuse cycle $[16,28]$. The reduction of the residual activity of the enzymes during the recycling test could be due to product inhibition, mechanical damage, or deactivation of the enzyme [31,32]. This effect was attributed to leakage of the enzyme from the support, due to the lixiviation of non-covalently bound enzyme molecules adsorbed on the support during the first reaction cycle. This work provides an opportunity to reduce enzyme consumption during the saccharification of lignocellulosic materials for the production of oligosaccharides, among other processes.

\section{Materials and Methods}

\subsection{Materials}

Genipin (90\% w/w purity) was provided by Guangxi SYBiochemical Science \& Technology Co., Liuzhou, Guangxi, China. Xylanase (endo- $\beta-1,4$-xylanase from Trichoderma longibrachiatum $\geq 2.5 \mathrm{U} / \mathrm{mg}$ ), filter paper-ase (cellulase from Trichoderma viride $\geq 3-10 \mathrm{U} / \mathrm{mg}$ ), low-molecular-weight chitosan (50-190 kDa, 75\%-85\% deacetylation), and all other chemicals were provided by Sigma-Aldrich (St. Louis, MO, USA), except those indicated.

\subsection{Preparation of Chitosan-Coated Magnetite Particles ( $\mathrm{Fe}_{3} \mathrm{O}_{4} @$ @Chitosan) and Enzyme Immobilization ( $\mathrm{Fe}_{3} \mathrm{O}_{4} @$ Chitosan@Enzymes)}

The chitosan magnetic composite and enzyme immobilization were performed as described by [22]. The magnetite particles coated with chitosan were obtained by in situ co-precipitation of $\mathrm{Fe}^{2+}: \mathrm{Fe}^{3+}$ salt solution in a chitosan template. For enzyme immobilization, $300 \mathrm{mg}$ of $\mathrm{Fe}_{3} \mathrm{O}_{4} @$ Chitosan dispersed in $45 \mathrm{mg} / \mathrm{mL}$ of a mixture of xylanase and cellulase were covalently bound with genipin $(0.01 \% w / v)$ in $50 \mathrm{mM}$ acetate buffer at $\mathrm{pH} 4.5$. The reaction mixture was incubated at room temperature $\left(25 \pm 1^{\circ} \mathrm{C}\right)$ for one hour. Then, the immobilized enzymes $\left(\mathrm{Fe}_{3} \mathrm{O}_{4} @\right.$ Chitosan@Enzymes) were collected from the reaction using an external neodymium magnet (1.2 T), rinsed with ethanol $70 \% v / v$ and then with Milli-Q water, and speed vac dried (DyNA vap centrifugal evaporator, Labnet, Edison, NJ, USA) 
at $60{ }^{\circ} \mathrm{C}$. The immobilization yield (Equation (1)), immobilization efficiency (Equation (2)), and activity recovery (Equation (3)) were calculated according to [23] in terms of total hydrolytic activity by using a mixture of substrates.

$$
\begin{gathered}
\text { Yield }(\%)=100 \% *\left(\frac{\text { immobilized activity }}{\text { starting activity }}\right) \\
\text { Efficiency }(\%)=100 \% *\left(\frac{\text { observed activity }}{\text { immobilized activity }}\right) \\
\text { Activity recovery }(\%)=100 \% *\left(\frac{\text { observed activity }}{\text { starting activity }}\right)
\end{gathered}
$$

\subsection{Enzyme Activity Assay}

The endo-1,4- $\beta$-D-xylanase EC 3.2.1.8 and the total cellulolytic activity or filter paper-ase (FPase, which comprises four enzymes: endo-1,4- $\beta$-D-glucanase (EC 3.2.1.4), exo-glucanase, 1,4- $\beta$-D-glucan-cellobiohydrolase (EC 3.2.1.91), and $\beta$-glucosidase (EC 3.2.1.21)), for cellulose degradation were assayed. Activities were quantified determining the amount of reducing sugars (xylose or glucose equivalent) released from beechwood xylan $(3 \mathrm{mg})$ and filter paper Whatman No. 5 (10 mg) in $10 \mathrm{~min}$ and $30 \mathrm{~min}$, respectively, using 3,5-dinitrosalicylic acid (DNS) reagent, at the proper temperature [33]. One milliliter of the final volume of enzymatic reaction contained $10 \mathrm{mg}$ of $\mathrm{Fe}_{3} \mathrm{O}_{4} @$ Chitosan@Enzymes, $4.8 \mu \mathrm{M}$ and $6.0 \mu \mathrm{M}$ of free xylanase and cellulase, respectively, as previously described [34]. Then, the $\mathrm{Fe}_{3} \mathrm{O}_{4} @$ Chitosan@Enzymes were removed from the reaction medium using an external magnetic field and the hydrolytic reaction was stopped by adding the DNS reagent. The total hydrolytic activity was determined by quantifying reducing sugars released from a mixture of both substrates in $50 \mathrm{mM}$ citrate-phosphate buffer $\mathrm{pH} 5$ at $50{ }^{\circ} \mathrm{C}$ for $10 \mathrm{~min}$. Controlled experiments were performed by adding nanoparticles without immobilized enzymes. One unit (U) of xylanase and FPase activity was defined as the amount of enzyme catalyzing the release of $1 \mu \mathrm{mol}$ of reducing sugar as xylose or glucose equivalent per minute under the specified assay conditions.

\subsection{Effect of Temperature and $p H$ on Xylanase and FPase Activity}

To evaluate the effect of temperature on the activity of both free and immobilized xylanase and FPase, enzymatic reactions were incubated at $30-90^{\circ} \mathrm{C}$, using $50 \mathrm{mM}$ citrate-phosphate buffer $\mathrm{pH}$ 5.0. The activation energy (Ea) of enzymes was determined by plotting $\ln$ (activity) vs. (reciprocal of absolute temperature, 1/K) according to the Arrhenius equation [35]. Ea was determined in the temperatures where an increment in the activity was observed. From the slope of the plot $(-\mathrm{Ea} / \mathrm{R})$ was obtained, where $\mathrm{R}$ is the universal gas constant. Xylanase and FPase activity were quantified using a $50 \mathrm{mM}$ citrate-phosphate buffer for $\mathrm{pH}$ values 3.0 to 7.0, a $50 \mathrm{mM}$ phosphate buffer for $\mathrm{pH} 8.0$, and a $50 \mathrm{mM}$ glycine buffer for $\mathrm{pH} 9.0$ and 10.0, at the temperature of maximum activity.

\subsection{Kinetic Parameters of Xylanase and FPase}

The relation between substrate concentration and reaction rate of free and immobilized xylanase and FPase were determined using beechwood xylan and filter paper concentrations of $0-6.7 \mathrm{mg} / \mathrm{mL}$ and $0-100 \mathrm{mg} / \mathrm{mL}$, respectively, at the $\mathrm{pH}$ and temperature where maximum activity was observed

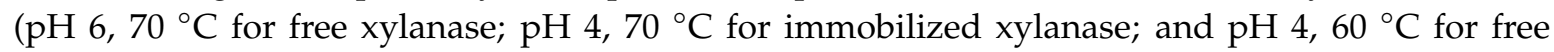
and immobilized FPase). The apparent Michaelis-Menten constant $(\mathrm{Km})$ and maximum catalytic velocity (Vmax) values were obtained using a Lineweaver-Burk plot for free and immobilized enzyme employing the SigmaPlot 13.0 software (Systat Software, San Jose, CA, USA). 


\subsection{Reuse Capacity of $\mathrm{Fe}_{3} \mathrm{O}_{4} @$ Chitosan@Enzymes}

The reuse capacity was assayed by 10 min incubation of the $\mathrm{Fe}_{3} \mathrm{O}_{4} @$ chitosan@enzymes at the temperature and $\mathrm{pH}$ of maximum activity for each enzyme, thus determining the enzymatic activity. At the end of the reaction, the immobilized enzymes were separated by applying a magnetic field (1.4 T), washed with citrate-phosphate buffer ( $50 \mathrm{mM}, \mathrm{pH} 4.0)$, and then transferred to a new reaction medium to start the next reaction cycle. A plot of the log percent residual activity vs. time was obtained and the slope was used to calculate the inactivation rate constant $(\mathrm{k})$, and the time required to decrease activity to half its original value $\left(\mathrm{t}_{1 / 2}\right)$ was calculated as $0.693 / \mathrm{k}$. The enzymatic activity in the first cycle was fixed as $100 \%$.

\section{Conclusions}

The use of chitosan and genipin contributes to a significant reduction of toxicity risk, making them a suitable and eco-friendly alternative to synthetic compounds, corresponding to the rising demand for natural products. Cross-linking significantly improved the biochemical properties of immobilized enzymes by the unique reorganization of the polymeric matrix. The paramagnetic property shown by the support allowed easy removal and recovery of the immobilized enzymes by using a magnetic field. The quick and operative immobilization and reuse methods of individual and immobilized multienzymatic systems offer the possibility of cost reduction in biotechnological applications. Multi-enzyme immobilization alternatives still require huge efforts, but after understanding the activity changes during immobilization, the design of reusable, efficient, and practical multi-enzyme co-immobilization technology is feasible for industrial applications.

Author Contributions: Conceptualization, A.A.-R.; Formal analysis, J.G. and B.E.G.-A.; Funding acquisition, A.A.-R.; Investigation, A.D.-H. and T.A.-O.; Methodology, A.A.-R. and C.R.; Visualization, M.E.-G. and T.A.-O.; Writing—original draft, A.A.-R.; Writing—review and editing, A.A.-R. and C.R.

Funding: This research was funded by Consejo Nacional de Ciencia y Tecnología, Mexico (CB-2014-241208). The publication fee was funded by Programa para el Desarrollo Profesional Docente de la Secretaría de Educación Pública of Mexico.

Conflicts of Interest: The authors declare no conflicts of interest.

\section{References}

1. Naskar, S.; Koutsu, K.; Sharma, S. Chitosan-based nanoparticles as drug delivery systems: A review on two decades of research. J. Drug Target. 2019, 27, 379-393. [CrossRef] [PubMed]

2. Neri-Numa, I.A.; Pessoa, M.G.; Paulino, B.N.; Pastore, G.M. Genipin: A natural blue pigment for food and health purposes. Trends Food Sci. Technol. 2017, 67, 271-279. [CrossRef]

3. Tokareva, M.I.; Ivantsova, M.N.; Mironov, M.A. Heterocycles of natural origin as non-toxic reagents for cross-linking of proteins and polysaccharides. Chem. Heterocycl. Compd. 2017, 53, 21-35. [CrossRef]

4. Flores, E.E.E.; Cardoso, F.D.; Siqueira, L.B.; Ricardi, N.C.; Costa, T.H.; Rodrigues, R.C.; Klein, M.P.; Hertz, P.F. Influence of reaction parameters in the polymerization between genipin and chitosan for enzyme immobilization. Process Biochem. 2019, 84, 73-80. [CrossRef]

5. Gracida, J.; Arredondo-Ochoa, T.; García-Almendárez, B.E.; Escamilla-García, M.; Shirai, K.; Regalado, C.; Amaro-Reyes, A. Improved thermal and reusability properties of xylanase by genipin cross-linking to magnetic chitosan particles. Appl. Biochem. Biotechnol. 2019, 188, 395-409. [CrossRef]

6. Gür, S.D.; İdil, N.; Aksöz, N. Optimization of enzyme co-immobilization with sodium alginate and glutaraldehyde-activated chitosan beads. Appl. Biochem. Biotechnol. 2018, 184, 538-552. [CrossRef]

7. Çakmakçi, E.; Yuce-Dursun, B.; Demir, S. Maleic anhydride functionalization of OSTE based coatings via thiol-ene "Click" reaction for the covalent immobilization of xylanase. React. Funct. Polym. 2017, 111, 38-43. [CrossRef]

8. Cipolatti, E.P.; Valério, A.; Henriques, R.O.; Moritz, D.E.; Ninow, J.L.; Freire, D.M.G.; Manoel, E.A.; Fernandez-Lafuente, R.; de Oliveira, D. Nanomaterials for biocatalyst immobilization-State of the art and future trends. RSC Adv. 2016, 6, 104675-104692. [CrossRef] 
9. Rodrigues, R.C.; Ortiz, C.; Berenguer-Murcia, Á.; Torres, R.; Fernández-Lafuente, R. Modifying enzyme activity and selectivity by immobilization. Chem. Soc. Rev. 2013, 42, 6290-6307. [CrossRef]

10. Ren, S.; Li, C.; Jiao, X.; Jia, S.; Jiang, Y.; Bilal, M.; Cui, J. Recent progress in multienzymes co-immobilization and multienzyme system applications. Chem. Eng. J. 2019, 373, 1254-1278. [CrossRef]

11. Yang, S.-Q.; Dai, X.-Y.; Wei, X.-Y.; Zhu, Q.; Zhou, T. Co-immobilization of pectinase and glucoamylase onto sodium aliginate/graphene oxide composite beads and its application in the preparation of pumpkin-hawthorn juice. J. Food Biochem. 2019, 43, e12741. [CrossRef] [PubMed]

12. Muley, A.B.; Thorat, A.S.; Singhal, R.S.; Babu, K.H. A tri-enzyme co-immobilized magnetic complex: Process details, kinetics, thermodynamics and applications. Int. J. Biol. Macromol. 2018, 118, 1781-1795. [CrossRef] [PubMed]

13. De Lima Damásio, A.R.; Pessela, B.C.; da Silva, T.M.; Guimarães, L.H.S.; Jorge, J.A.; Guisán, J.M.; Polizeli, M.D.L.T.M. Co-immobilization of fungal endo-xylanase and $\alpha$-L-arabinofuranosidase in glyoxyl agarose for improved hydrolysis of arabinoxylan. J. Biochem. 2013, 154, 275-280. [CrossRef] [PubMed]

14. Torres, P.; Batista-Viera, F. Production of d-tagatose and d-fructose from whey by co-immobilized enzymatic system. Mol. Catal. 2019, 463, 99-109. [CrossRef]

15. Rodrigues, R.C.; Virgen-Ortíz, J.J.; dos Santos, J.C.S.; Berenguer-Murcia, Á.; Alcantara, A.R.; Barbosa, O.; Ortiz, C.; Fernandez-Lafuente, R. Immobilization of lipases on hydrophobic supports: Immobilization mechanism, advantages, problems, and solutions. Biotechnol. Adv. 2019, 37, 746-770. [CrossRef]

16. Da Silva, R.M.; Souza, P.M.P.; Fernandes, F.A.N.; Gonçalves, L.R.B.; Rodrigues, S. Co-immobilization of dextransucrase and dextranase in epoxy-agarose-tailoring oligosaccharides synthesis. Process Biochem. 2019, 78, 71-81. [CrossRef]

17. Nadar, S.S.; Rathod, V.K. A co-immobilization of pectinase and cellulase onto magnetic nanoparticles for antioxidant extraction from waste fruit peels. Biocatal. Agric. Biotechnol. 2019, 17, 470-479. [CrossRef]

18. Periyasamy, K.; Santhalembi, L.; Mortha, G.; Aurousseau, M.; Subramanian, S. Carrier-free co-immobilization of xylanase, cellulase and $\beta-1,3$-glucanase as combined cross-linked enzyme aggregates (combi-CLEAs) for one-pot saccharification of sugarcane bagasse. RSC Adv. 2016, 6, 32849-32857. [CrossRef]

19. Bilal, M.; Zhao, Y.; Rasheed, T.; Iqbal, H.M.N. Magnetic nanoparticles as versatile carriers for enzymes immobilization: A review. Int. J. Biol. Macromol. 2018, 120, 2530-2544. [CrossRef]

20. Assa, F.; Jafarizadeh-Malmiri, H.; Ajamein, H.; Anarjan, N.; Vaghari, H.; Sayyar, Z.; Berenjian, A. A biotechnological perspective on the application of iron oxide nanoparticles. Nano Res. 2016, 9, 2203-2225. [CrossRef]

21. Sperandio, G.B.; Filho, E.X.F. Fungal co-cultures in the lignocellulosic biorefinery context: A review. Int. Biodeterior. Biodegrad. 2019, 142, 109-123. [CrossRef]

22. Díaz-Hernández, A.; Gracida, J.; García-Almendárez, B.E.; Regalado, C.; Núñez, R.; Amaro-Reyes, A. Characterization of magnetic nanoparticles coated with chitosan: A potential approach for enzyme immobilization. J. Nanomater. 2018, 2018, 9468574. [CrossRef]

23. Sheldon, R.A.; van Pelt, S. Enzyme immobilisation in biocatalysis: Why, what and how. Chem. Soc. Rev. 2013, 42, 6223-6235. [CrossRef] [PubMed]

24. Ma, H.-F.; Meng, G.; Cui, B.-K.; Si, J.; Dai, Y.-C. Chitosan crosslinked with genipin as supporting matrix for biodegradation of synthetic dyes: Laccase immobilization and characterization. Chem. Eng. Res. Des. 2018, 132, 664-676. [CrossRef]

25. Mak, Y.W.; Leung, W.W.-F. Crosslinking of genipin and autoclaving in chitosan-based nanofibrous scaffolds: Structural and physiochemical properties. J. Mater. Sci. 2019, 54, 10941-10962. [CrossRef]

26. Sánchez-Ramírez, J.; Martínez-Hernández, J.L.; Segura-Ceniceros, P.; López, G.; Saade, H.; Medina-Morales, M.A.; Ramos-González, R.; Aguilar, C.N.; Ilyina, A. Cellulases immobilization on chitosan-coated magnetic nanoparticles: Application for Agave atrovirens lignocellulosic biomass hydrolysis. Bioprocess Biosyst. Eng. 2017, 40, 9-22. [CrossRef]

27. Salgaonkar, M.; Nadar, S.S.; Rathod, V.K. Combi-metal organic framework (Combi-MOF) of $\alpha$-amylase and glucoamylase for one pot starch hydrolysis. Int. J. Biol. Macromol. 2018, 113, 464-475. [CrossRef]

28. Carli, S.; Carneiro, L.A.B.D.C.; Ward, R.J.; Meleiro, L.P. Immobilization of a $\beta$-glucosidase and an endoglucanase in ferromagnetic nanoparticles: A study of synergistic effects. Protein Expr. Purif. 2019, 160, 28-35. [CrossRef] 
29. Nadar, S.S.; Rathod, V.K. Magnetic macromolecular cross linked enzyme aggregates (CLEAs) of glucoamylase. Enzym. Microb. Technol. 2016, 83, 78-87. [CrossRef]

30. Shahrestani, H.; Taheri-Kafrani, A.; Soozanipour, A.; Tavakoli, O. Enzymatic clarification of fruit juices using xylanase immobilized on 1,3,5-triazine-functionalized silica-encapsulated magnetic nanoparticles. Biochem. Eng. J. 2016, 109, 51-58. [CrossRef]

31. Mafra, A.C.O.; Ulrich, L.G.; Kornecki, J.F.; Fernandez-Lafuente, R.; Tardioli, P.W.; Ribeiro, M.P.D.A. Combi-CLEAs of glucose oxidase and catalase for conversion of glucose to gluconic acid eliminating the hydrogen peroxide to maintain enzyme activity in a bubble column reactor. Catalysts 2019, 9, 657. [CrossRef]

32. Sojitra, U.V.; Nadar, S.S.; Rathod, V.K. A magnetic tri-enzyme nanobiocatalyst for fruit juice clarification. Food Chem. 2016, 213, 296-305. [CrossRef] [PubMed]

33. Miller, G.L. Use of dinitrosalicylic acid reagent for determination of reducing sugar. Anal. Chem. 1959, 31, 426-428. [CrossRef]

34. Amaro-Reyes, A.; Gracida, J.; Huizache-Peña, N.; Elizondo-García, N.; Salazar-Martínez, J.; García-Almendárez, B.E.; Regalado, C. On-site hydrolytic enzymes production from fungal co-cultivation of Bermuda grass and corn cob. Bioresour. Technol. 2016, 212, 334-337. [CrossRef] [PubMed]

35. Goluguri, B.R.; Thulluri, C.; Addepally, U.; Shetty, P.R. Novel alkali-thermostable xylanase from Thielaviopsis basicola (MTCC 1467): Purification and kinetic characterization. Int. J. Biol. Macromol. 2016, 82, 823-829. [CrossRef] [PubMed]

(C) 2019 by the authors. Licensee MDPI, Basel, Switzerland. This article is an open access article distributed under the terms and conditions of the Creative Commons Attribution (CC BY) license (http://creativecommons.org/licenses/by/4.0/). 